C. Vladeck, Director, Health Care Financing Administration, U.S. Department of Health and Human Services. Vladeck received his Ph.D. in political science from the University of Michigan. Washington Post national correspondent E.J. Dionne was selected as winner of the 1996 Carey McWilliams Award honoring his contribution to our understanding of politics.

Details on awards presented by the Organized Sections appears later in Association News.

\section{APSA Welcomes Graduate Students at San Francisco Meeting}

Graduate students are an integral part of the APSA Annual Meeting, and this year over 1500 attended. Graduate students delivered papers in the approximately 650 panels and roundtables during the 1996 meeting, and could also be found among the 250 scholars presenting posters at the Annual Meeting poster sessions.

Several events and services targeted graduate students in San Francisco, including two forms of informal exchanges with senior scholars. "Breakfast with Champions" gave students the opportunity to participate in relaxed roundtable discussions with renowned political scientists. Discussions ranged from career planning and networking relationships, to balancing family responsibilities, formulating research, and improvements in teaching skills.

At the Annual Meeting's Leading Scholar series, the graduate students participated in roundtable sessions with two legendary scholars. Gabriel A. Almond and Heinz Eulau, both of Stanford University and both former APSA presidents, discussed the evolution of political science, and the controversies that have reconstructed the discipline in recent decades.

The Professional Placement Service, located in the Hotel Nikko San Francisco, attracted over 600 applicants. The Service offers an opportunity for institutions to meet job candidates face-to-face and discuss prospective employment opportuni-

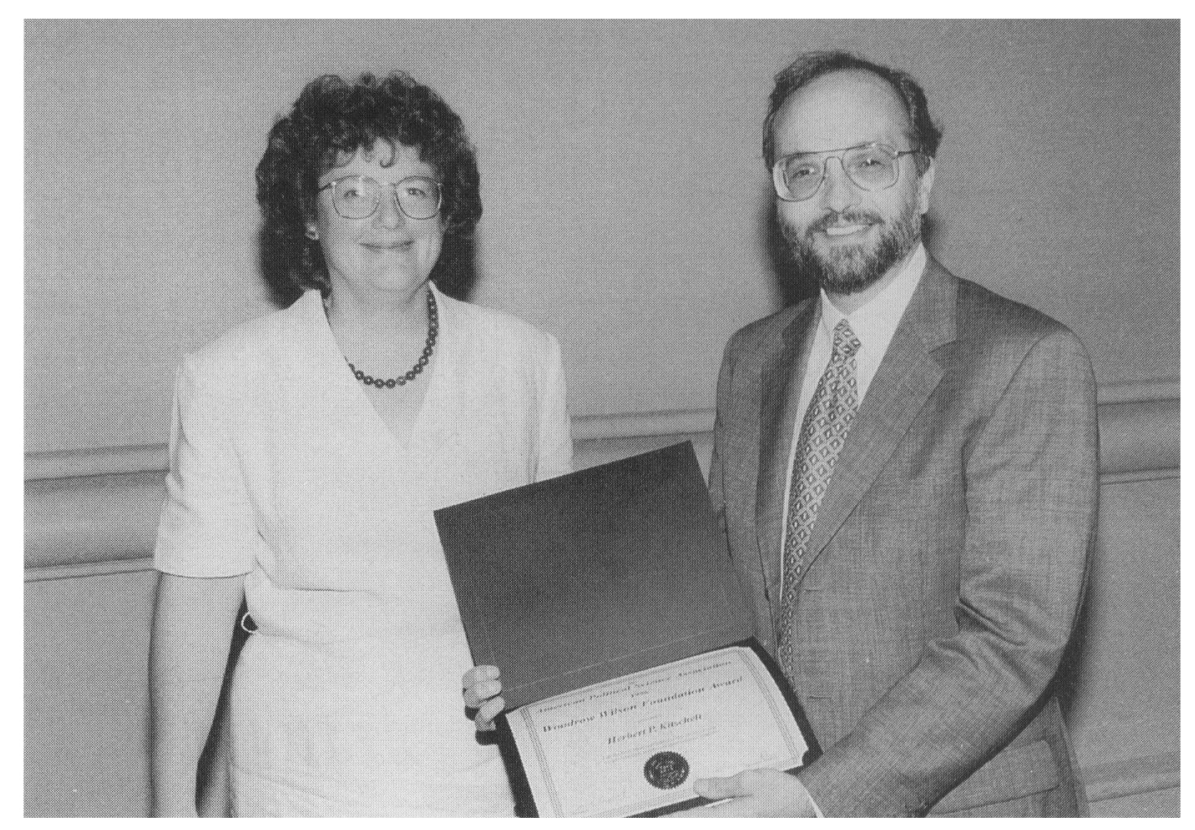

Herbert Kitschelt, Duke University, receives the Woodrow Wilson Foundation Award for the best book published in 1995 on government, politics, or international affairs. Title of his book: The Radical Right in Western Europe (University of Michigan Press). Presenting the award is Virginia Sapiro, University of Wisconsin-Madison, Award Committee Chair.

ties. This year 96 institutions were represented and 177 job openings were posted.

Finally, students attended the Annual Graduate Student Reception, where they received a special welcome from President Arend Lijphart and President-Elect Elinor Ostrom. Held at the Crowne Plaza Parc Fifty-Five Hotel, students mingled with other students and with many of the nation's most respected political scientists.

\section{APSA Awards Advanced Graduate Student Travel Grants}

In a continuing effort to assist graduate students slated to present papers at the annual meeting, the Association again offered its Advanced Graduate Student Travel Grant Program. With funding through the APSA Council, 18 travel grants were awarded. Nearly 90 applications were submitted. The names and affiliations of winners follow:

Russell Lightfoot, Miami University Tom Lewis, University of Washington

Steven Lobell, University of California-Los Angeles
Kira Poplowski, University of California-Santa Barbara

J. L. Jeffries, University of Southern California

Gene Brewer, University of Georgia Andrew Barnes, Princeton University Jeff J. Corntassel, University of Arizona

Patrice M. Mareschal, University of Oklahoma

Scott H. Huffmon, University of Mississippi

Peter Stone, University of Rochester

Robert H. Bruhl, University of Illinois at Chicago

Janice M. Googin, Brown University Marie Gottschalk, Yale University

Paul G. Harris, Brandeis University

Paul A. Harris, Auburn University

Heather Trippel, Purdue University

Douglas M. Gibler, Vanderbilt University

\section{Annual Meeting Short Courses Promote Professional Development}

Ten short courses were offered in San Francisco the day before this year's Annual Meeting began. As part of the Annual Meeting's "Professional Day" program, several APSA Organized Sections and the National Issues Forum sponsored 


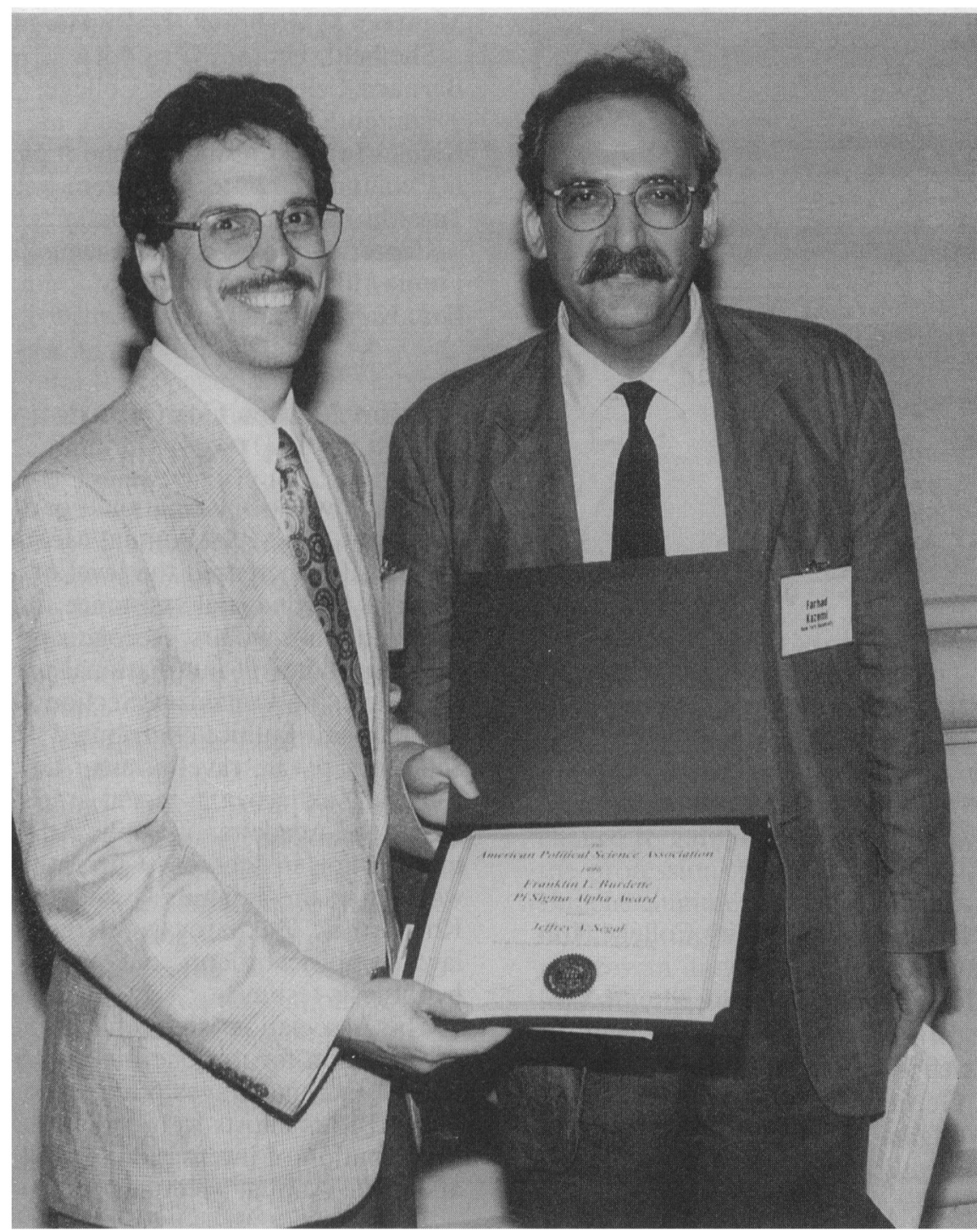

Farhad Kazemi, New York University, chair of the Franklin L. Burdette Pi Sigma Alpha Award for the best paper presented at the 1995 Annual Meeting honors the 1996 recipient, Jeffrey A. Segal, SUNY-Stony Brook, for his paper "Marksist (and Neo-Marksist) Models of Supreme Court Decision Making: Separation-of-Powers in the Positive Theory of Law and Courts."

workshops where political scientists and graduate students learned about teaching and research skills, developed computer expertise, and heard senior scholars reflect on the profession. Nearly 150 Annual Meeting attendees participated in this year's short course program.

Short courses this year included the Leading Scholar Series which featured Gabriel A. Almond and Heinz Eulau, both of Stanford University and both former APSA presidents. This session served as an extraordinary opportunity for graduate students to meet two high-profile political scientists and gain from their insight into the profession.

The program also included courses on the Internet and World Wide Web technologies and a course on databases available for legal research. Other courses offered opportunities to learn about teaching gender and politics, teaching citizen participation, and acting as a pre-law advisor to undergraduates. Workshops on defense and security in contemporary Asia, constitutional democracies, and California state politics in the 1990 s were also included in the program.

Plans for the 1997 Short Course Program are presently underway. Those interested in sponsoring short courses at the 1997 Annual Meeting should contact Rob Hauck, Deputy Director of APSA.

\section{Travel Grants Bring International Scholars to Meeting}

In an effort to assist international scholars participating at the annual meeting in San Francisco, the Association was able to secure travel funding for 50 scholars, including 28 senior scholars and 22 international students enrolled in american universities. A list of international grantees, their countries, and their U.S. affiliations follows:

Therese S. Gunawardena, University of Texas at Austin, Sri Lanka

Shyama Venkateswar, Columbia University, India

Himadeep Muppidi, University of Minnesota, India

Norrin M. Ripsman, University of Pennsylvania, Canada

Erik Duchesne, Michigan State University, Canada

Howard G. Romanko, University of Arizona, Canada

Jin Yu, California Institute of Technology, P.R. China

Ming Xia, Temple University, P.R. China

Tong-yi Huang, University of Texas at Austin, Taiwain

Aurelian Craiutu, Princeton University, Romania

Ching-ping Tang, University of Southern California, Taiwain

Heajeong Lee, Northwestern University, Korea

Francisco David Rueda, Cornell University, Spain

Valentina L. Padula, University of Maryland, Italy

Henry Laurence, Harvard University, United Kingdom

Carlos Pereira, New School for Social Research, Brazil

Anibal Perez Linan, University of Notre Dame, Argentina

Jakob Zielinski, University of Chicago, Poland

Demet Yalcin, Binghamton University, Turkey

Okiyoshi Takeda, Princeton University, Japan

Juchan Kim, George Washington University, Korea

Soo Yeon Kim, Yale University, Korea 